\title{
MỘT SỐ KẾT QUẢ NGHIÊN CÚU MỚI VỀ ĐẶC ĐIỂM PHÂN BỐ VÀ THÀNH PHẦN VẬT CHẤT CỦA QUẬNG HÓA TRONG KHU VỰC MỎ CHÌ - KẼM NA SƠN
}

\author{
BÙI ÂN NIÊN, TRẦN TRỌNG HÒA, TRẦ TUẤN ANH, PHẠM THI DUNG, \\ PHẠM NGỌC CẨN, TRẦN VĂN HIẾU, TRÂN QUỐC HỦNG, NGÔ THỊ PHƯợNG
}

E-mail: nienba54@yahoo.com.vn

Viện Địa chất - Viện Khoa học và Công nghệ Việt Nam

Ngày nhận bài: 01-9-2010

\section{Mở đầu}

Vùng mỏ Na Sơn từ lâu đã được nhiều nhà địa chất quan tâm nghiên cứu và đều có những nhận định chung về triển vọng công nghiệp của quặng chì-kẽm phân bố ở khu vực này. Tuy nhiên, những yếu tố quan trọng như: đặc điểm địa chất khống chế quặng, mối quan hệ giữa quặng hóa với các thành tạo vây quanh, đặc điểm hình thái cấu kiến trúc và thành phần vật chất quặng hóa (thành phần khoáng vật, thành phần hóa học, hành vi địa hóa của các nguyên tố)... làm cơ sở cho việc luận giải nguồn gốc và cơ chế thành tạo của mỏ quặng chưa được làm sáng tỏ.

Từ trước đến nay, các mỏ chì-kẽm ở Việt Nam nói chung và ở mỏ Na Sơn nói riêng chỉ mới tập trung khai thác chế biến hai loại quặng kẽm (sphalerit) và chì (galenit) là chủ yếu, các nguyên tố quý hiếm đi kèm như $\mathrm{Cd}, \mathrm{In}, \mathrm{Ag}, \mathrm{Cu}, \mathrm{Sb}, \mathrm{Mo}$, TR... có ý nghĩa làm tăng giá trị kinh tế của mỏ quặng hầu như chưa được quan tâm nghiên cứu.

Khắc phục được những tồn tại như đã nêu ở trên là một trong những công việc rất phức tạp, cần thiết phải tiến hành nghiên cứu chi tiết cả ngoài thực địa lẫn trong phòng thí nghiệm. Đặc biệt là trong nghiên cứu thành phần vật chất của quặng hóa, cần phải thu thập các mẫu sao cho đại diện nhất ở các vị trí khác nhau ngoài thực địa, đồng thời tiến hành phân tích nhiều loại mẫu bằng nhiều phương pháp khác nhau để có bộ kết quả tốt nhất giúp cho việc dự đoán quy mô, triển vọng và giá trị kinh tế của mỏ quặng. Đây là một trong những nhiệm vụ hết sức quan trọng đồng thời đó cũng chính là nội dung của bài báo mà tập thể tác giả sẽ trình bày dưới đây.

\section{Khái quát về đặc điểm địa chất - thạch học khu vực mỏ Na Sơn}

Mỏ chì-kẽm $\mathrm{Na}$ Sơn nằm trong địa phận xã Tòng Bá, huyện Vị Xuyên, tỉnh Hà Giang, cách thị xã Hà Giang khoảng $13 \mathrm{~km}$ về phía Đông Bắc, với tọa độ trung tâm: $22^{\circ} 55^{\prime} 20,4^{\prime \prime}$ vỹ độ bắc; $105^{\circ} 04^{\prime} 47,7^{\prime \prime}$ kinh độ đông.

Về phương diện địa chất, khu vực $\mathrm{Na}$ Sơn Tòng Bá là bộ phận nhỏ trong đới nâng sông Lô [2, $13,14]$, hoặc trong phạm vi của đới cấu trúc Khao Lộc $[11,15]$. Địa bàn nghiên cứu nằm ở phần trung tâm nếp lõm Tòng Bá, do ảnh hưởng của hoạt động kiến tạo đất đá ở đây bị đẩy trồi lên, tạo thành khối cấu tạo Tòng Bá có đặc điểm kiến trúc và sinh khoáng khác biệt so với xung quanh.

Những kết quả nghiên cứu địa chất trước đây ở khu vực này về cơ bản đã xác lập được bình đồ cấu trúc chung của vùng nghiên cứu, song về địa tầng lại có những quan điểm khác nhau: các đá rõ ràng có cùng vị trí và cùng thành phần nhưng chúng lại được xếp vào các phân vị có tuổi rất khác nhau, trật tự trầm tích không thống nhất. Chẳng hạn, các thành tạo trầm tích lục nguyên-carbonat xen phun trào phân bố ở Na Sơn được Tạ Hoàng Tinh (1971) 
xếp vào điệp Cao Vinh $\left(\mathrm{D}_{2} c v\right)$. Khi hiệu đính loạt tờ Đông Bắc tỷ lệ 1:200.000, Phan Sơn và Vũ Ngọc Hải (1994), Hoàng Xuân Tình (2001) đã xêp chúng vào hệ tầng Tòng $B a ́\left(\mathrm{D}_{1} t b\right), \ldots$ Nguyên nhân cơ bản dẫn đến tình trạng trên có lẽ do mức độ khảo sát địa chất ở các bản đồ tỷ lệ nhỏ còn thưa, đá lộ kém và bị biến chất không đồng đều, hoá thạch thu thập được quá ít...do vâyy trật tự địa tầng trong vùng chủ yều được xác lập nhờ đố sánh với các vùng xung quanh và có nhiều biến động là điều khó tránh khỏi.

Chúng tôi chấp thuận quan điểm với các tài liệu mới của [11] đã xếp các thành tạo ở khu vực này vào hệ tầng Bản Cưởm $\left(\mathrm{D}_{1} \mathrm{bc}\right)$ cùng với các mô tả chi tiết hơn.

\section{1. Đặc điểm thạch học}

2.1.1. Hệ tầng: Khu mỏ Na Sơn chỉ chiếm một diện tích nhỏ vì vậy địa tầng khá đơn giảm, chủ yếu lộ ra phân hệ 2 của hệ tầng Bản Cưởm (hình 1), bao gồm các biến loại: phiến thạch anh felspat mica, phiến silic, phiến sericit,... có đặc trưng phân phiến mỏng, phân bố thành từng tập xen kẽ cùng với ryolit biến đổi. Đá có cấu tạo dải, thế nằm chung $40-45^{\circ}<70-75^{\circ}$,

\section{SƠ ĐỔ ĐỊA CHÂT VÀ KHOÁNG SẢN KHU VỰC MỎ Pb-Zn NA SƠN}

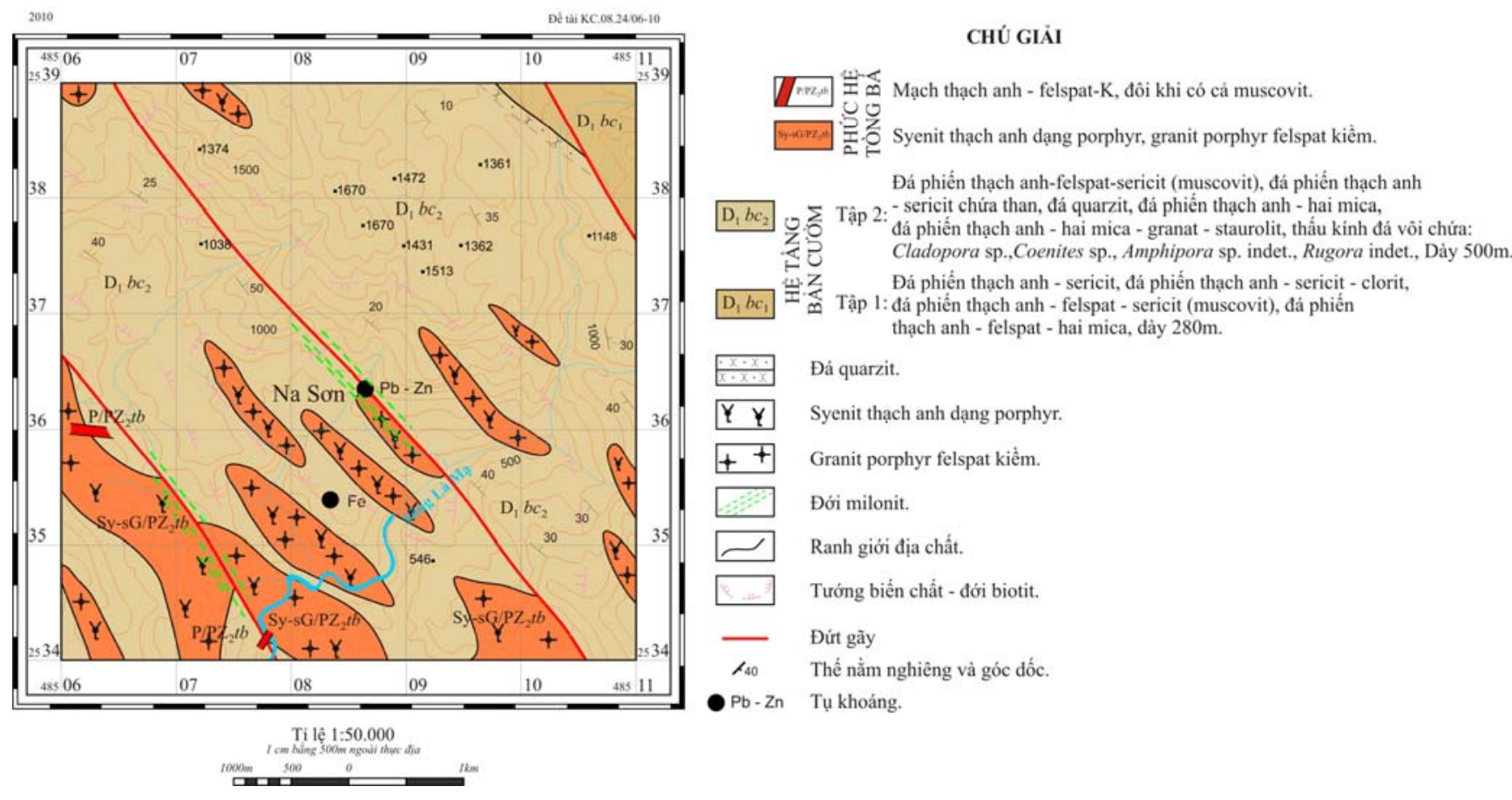

Hìn 1. Sơ đồ địa chất và khoáng sản khu vực mỏ chì-kẽm Na Sơn, tỷ lệ 1: 50.000 
một số nơi quan sát thấy quặng dạng mạch mỏng, dạng tia nhỏ, thấu kính nhỏ xuyên khớp đều theo mặt phân lớp của đá.

2.1.2. Các thành tạo magma: Phân bố trong khu vực nghiên cứu có khối Khuôn Làng và các thể nhỏ, mạch nhỏ với bề dày dao động từ vài mét đến hàng chục mét và kéo dài hàng trăm mét, chúng được xếp vào phức hệ Tòng Bá với các biến loại như sau:

- Granit biotit felspat kiềm dạng porphyr hạt nhỏ, màu xám trắng loang lổ, hồng nhạt với các ban tinh felspat kali màu hồng đỏ nhạt, biotit màu đen nâu, lượng thạch anh nhiều hơn felspat kali, đá có kiến trúc hạt nửa tự hình, granophyr, vi khảm.

- Syenit thạch anh biotit dạng porphyr, đá có màu xám phớt hồng với các ổ đốm hoặc dải màu đen của biotit. Thành phần gồm felspat kali dạng ban tinh khá đẳng thước và các ban tinh thạch anh. Đá có cấu tạo dạng porphyr, dạng khối, dạng phân dải,... kiến trúc hạt nửa tự hình, aplit, granophyr...

- Microsyenit thạch anh, microgranit felspat kiềm, các biến loại này là các tập phân bố theo dải dạng tuyến. Đá hạt nhỏ-mịn và ẩn tinh, đôi chỗ có mặt những vi ban tinh felspat kali màu hồng (kiểu ortophyr) và các ban tinh thạch anh (kiểu porphyr thạch anh), ban tinh chỉ chiếm 5-7\% thể tích đá. Trong trường hợp này nếu không quan sát kỹ quan hệ địa chất và sự phân bố không gian của chúng thì dễ ngộ nhận đó là các đá phun trào thực sự, đá có kiến trúc đặc trưng vi granophyr, vi khảm, trachyt và microspherolit.

- Ngoài ra, ryolit là biến loại chiếm phần lớn trong khu vực nghiên cứu, đá thường có màu xám nhạt, xám phớt hồng hoặc hồng nhạt loang lổ, bị ép nén đến phân phiến thành các dải xen kẽ cùng với các tập đá phiến silic, phiến amphibol,... Nhiều nơi còn quan sát thấy đá bị biến đổi mạnh thành phiến sericit hoặc phiến thạch anh mica,...

Do ảnh hưởng của hoạt động kiến tạo, hầu hết các đá phân bố trong khu vực nghiên cứu bị xiết ép, rạn nứt được lấp đầy bởi các loại quặng sulfur khác nhau. Ngoài ra ở những nơi có đứt gãy kiến tạo cắt qua, đá thường bị cà nát mạnh, phổ biến hiện tượng phiến hóa, milonit hóa tạo điều kiện thuận lợi cho dung dịch quặng thấm lọc và kết đọng thành các mạch và ổ quặng đặc sít.

\section{2. Đặc điểm cấu trúc kiến tạo}

Trong khu vực nghiên cứu các hệ thống đứt gãy kiến tạo rất phát triển, nhất là các đứt gãy theo phương Tây Bắc - Đông Nam (TB-ĐN), chúng có vai trò quan trọng đối với hoạt động magma và sinh khoáng.

Các đứt gãy nghịch có quy mô lớn nhất trong khu vực $[1,7,11]$, chạy dọc theo phương TB-ĐN với chiều dài trên $4 \mathrm{~km}$ cắt qua khu trung tâm $\mathrm{Na}$ Sơn. Biên độ dịch chuyển theo phương thẳng đứng khoảng 160-200m, đới phá hủy có chiều rộng 300$400 \mathrm{~m}$. Các đứt gãy thuận kéo dài trên $3 \mathrm{~km}$, hai bên đứt gãy bị vò nhàu cà nát mạnh, chiều rộng đới phá hủy $40-60 \mathrm{~m}$. Liên quan với hệ thống đứt gãy này là khoáng hóa sulfur chì - kẽm, chúng tạo thành các mạch hoặc thấu kính có giá trị công nghiệp. Các đứt gãy muộn hơn phát triển theo phương kinh tuyến và Đông Bắc - Tây Nam (ĐB-TN) có chiều dài khoảng $1 \mathrm{~km}$, đới phá hủy có chiều rộng khoảng $40-50 \mathrm{~m}$ với đứt gãy phương kinh tuyến và $30-$ $40 \mathrm{~m}$ với đứt gãy phương $\mathrm{ĐB}-\mathrm{TN}$, các đứt gãy này thường làm dịch trượt các thân quặng, gây khó khăn cho quá trình tìm kiếm, thăm dò.

\section{3. Đặc điểm phân bố và thành phần quặng hóa}

3.1. Đặc điển phân bố quặng hóa: Khu vực mỏ chì - kẽm Na Sơn có hai đới quặng:

Đới quặng I: phân bố ở độ cao $550 \mathrm{~m}$, thân quặng chính phát triển theo hướng bắc tây bắc, trùng với phương của đứt gãy kiến tạo, thế nằm khá thoải $\left(\sim 25^{\circ}\right)$, quặng dạng ổ mạch dày đặc kéo dài hoặc thành các lớp xuyên theo mặt phân phiến của các đá: phiến thạch anh sericit, phiến thạch anh amphybol và ryolit. Các đá vây quanh có thành phần gần như thuần túy felspat màu xám nhạt, hồng nhạt, thỉnh thoảng gặp các ổ và mạch thạch anh chứa chalcopyrit cắt qua. Thân quặng Ia (thân chính của đới quặng I), với thành phần chủ yếu là sphalerit chiếm gần $70 \%$ dưới dạng các vảy nhỏ màu nâu nhạt, dạng ổ hoặc mạch lấp đầy mặt phân phiến của đá. Galenit và các khoáng vật quặng nhóm oxyt, nhóm sulfur sắt có số lượng ít hơn. Các thân quặng phụ còn lại (Ib, Ic, Id) có phương kéo dài song song với thân quặng chính, khoảng cách giữa các thân quặng từ 2 đến $4 \mathrm{~m}$ và có dạng đứt quãng, kéo dài không liên tục khoảng $250 \mathrm{~m}$.

Đói quặng II: phân bố trên độ cao 840m (lò 4), $835 \mathrm{~m}$ (lò 3)... phát triển theo hướng bắc tây bắc, 
kéo dài $80-90 \mathrm{~m}$, thế nằm khá thoải $20-25^{\circ}$, đôi chỗ chỉ 5-8 . Quan sát tại lò số 4 cho thấy, thân quặng chính (thân quặng IIa) có dạng vỏ đậu, dài chừng 20-25m. Quặng đặt sít trong thân chính dày hàng mét với lượng galenit nhiều hơn sphalerit, kéo dài theo hướng phân bố của tập đá mycrosyenit thạch anh biotit màu hồng nhạt, xám nhạt. Ngoài hai loại quặng chính là chì và kẽm, trong thân quặng còn chứa một lượng đáng kể các khoáng vật như chalcopyrit, pyrit, quặng đồng xám, đôi khi cả pyrotin, magnetit,... Ngoài rìa thân quặng, lượng chì - kẽm giảm dần và thay vào đó là các mạch hay ổ chalcopyrit, pyrit, pyrotil...tụ tập lại đi cùng các mạch thạch anh, các khoáng vật này đôi khi đạt đến 2- 4\% thể tích. Trong đới quặng II, hầu hết các tập đá syenit, microsyenit thạch anh biotit, microgranit felspat kiềm màu nâu hồng nhạt, xám nhạt,... đều có chứa quặng chì - kẽm dưới dạng các ổ, mạch dày đặc gắn kết các mảnh đá dọc đới phá hủy kiến tạo hoặc dạng mạch nhỏ xuyên cắt chằng chịt theo các khe nứt tách của đá,... và có thể xem các tập đá này như một tập đánh dấu quặng.

\section{2. Đặc điểm thành phần quặng hóa}

Qua nghiên cứu thành phần khoáng vật các đới quặng trong khu vực mỏ $\mathrm{Na}$ Sơn cho thấy trong quặng hóa ở đây luôn có mặt các khoáng vật điển hình như sphalerit, galenit, chalcopyrit, tetraedrit, pyrit, ngoài ra còn gặp pyrotin, magnetit,... Thành phần hóa học của các khoáng vật quặng được thống kê trung bình từ 3 đến 5 điểm phân tích bằng phương pháp microzonde trên máy "CamebaxMicro”. Dưới đây là những đặc điểm cơ bản của các khoáng vật quặng chủ yếu.

Galenit $(\mathrm{PbS})$ là khoáng vật cùng với sphalerit có ý nghĩa công nghiệp chính ở mỏ Na Sơn, phân bố nhiều nhất trong đới quặng II. Galenit có mặt từ một vài đám hạt phân tán trong đá đến $65-70 \%$, thậm chí tập hợp thành những ổ, dải đặc sít chiếm đến $85-90 \%$. Dưới kính galenit có dạng mảnh khá sắc cạnh, vết vỡ hình bậc thang, màu xám chì, ánh kim mạnh với hai thế hệ:

- Thế hệ 1 gồm tập hợp các hạt nhỏ hay tấm nhỏ, tha hình, chúng cùng với pyrit thế hệ 1 tạo nên những xâm tán rời rạc không đồng đều trong đá.

- Thế hệ 2 gồm các tập hợp tha hình, dạng méo mó, kéo dài hoặc vát nhọn, thường lấp đầy khoảng trống giữa các khoáng vật khác hoặc phát triển dọc theo các khe nứt. Khá nhiều trường hợp quan sát thấy galenit chiếm khoảng không gian giữa sphalerit, pyrite hoặc cùng nhau xuyên cắt hoặc gặm mòn magnetit. Galenit cộng sinh chặt chẽ với sphalerit, pyrit, chalcopyrit nhưng hình thành muộn hơn và đôi khi còn tạo các bao thể trong sphalerit.

Kết quả phân tích thành phần hóa học của galenit (bảng 1 ) bằng phương pháp microzond ở mỏ $\mathrm{Na}$ Sơn cho thấy: $\mathrm{Pb}=85,11-88,16 \%, \mathrm{~S}=12,89$ $13,47 \%$, với giá trị này chúng tương đương với thành phần chính của galenit trong nhiều mỏ chìkẽm điển hình trên thế giới. Galenit ở đây đặc trưng có hàm lượng $\mathrm{Ag}$ khá cao $(0,04-0,12 \%, \mathrm{~TB}=$ $0,1 \%$, chúng xấp xỉ với hàm lượng $\mathrm{Ag}$ trong galenit ở các mỏ chì-kẽm được cho là giàu $\mathrm{Ag}$ trên thế giới $(\mathrm{Ag}=0,15-0,25 \%)$.

Sphalerit $(\mathrm{ZnS})$ phân bố với số lượng nhiều nhất trong đới quặng I, có mẫu đạt tới $>70 \%$ tổng lượng khoáng vật quặng, tuy nhiên cũng có mẫu chỉ là vài đám hạt đi cùng pyrit, pyrotin, arsenopyrit (phần rìa thân quặng). Sphalerit thường có mầu nâu xám, nâu đen, nâu vàng, vàng nhạt, ánh kim cương. Có hai thế hệ sphalerit được hình thành:

Bảng 1. Thành phần của các nguyên tố trong galenit vùng mỏ Na Sơn

\begin{tabular}{|c|c|c|c|c|c|c|c|c|}
\hline Ng. tố & $S$ & $\mathrm{~Pb}$ & $\mathrm{Fe}$ & $\mathrm{Bi}$ & Sn & $\mathrm{Ag}$ & $\mathrm{Sb}$ & Total \\
\hline Trung bình & 13,27 & 86,93 & 0,00 & 0,00 & 0,01 & 0,05 & 0,01 & 100,27 \\
\hline $\min$ & 12,89 & 85,11 & 0,00 & 0,00 & 0,00 & 0,00 & 0,00 & 98,25 \\
\hline $\max$ & 13,47 & 88,16 & 0,00 & 0,02 & 0,03 & 0,12 & 0,04 & 101,54 \\
\hline
\end{tabular}

- Thế hệ 1 gồm những hạt có kích thước nhỏ khá đẳng thước $(a ̉ n h ~ 1 ; B)$, trong biến loại này chứa các nhũ tương dạng vân mây của chalcopyrit
- là sản phẩm của quá trình phân hủy dung dịch cứng. Dưới kính phản quang nhiều trường hợp thấy sphalerit mọc xen với galenit, chalcopyrit và 
tetraedrit (ảnh 1; C, D), sphalerit loại này có phản chiếu bên trong màu vàng nâu, hay hung vàng.

- Thế hệ 2 gồm tập hợp tinh thể lớn tha hình, thường tạo thành các ô hoặc các dải mạch đặc xít, chúng thường có màu nâu tối, cát khai hoàn toàn theo 3 phương, hình dạng méo mó, đôi khi vát nhọn, kích thước $>1 \mathrm{~mm}$, trong chúng có chứa các bao thể galenit hình dạng kỳ dị kích thước tới $0,2 \mathrm{~mm}$ và các bao thể tetraedrit $(a ̉ n h ~ 1 ; A)$.
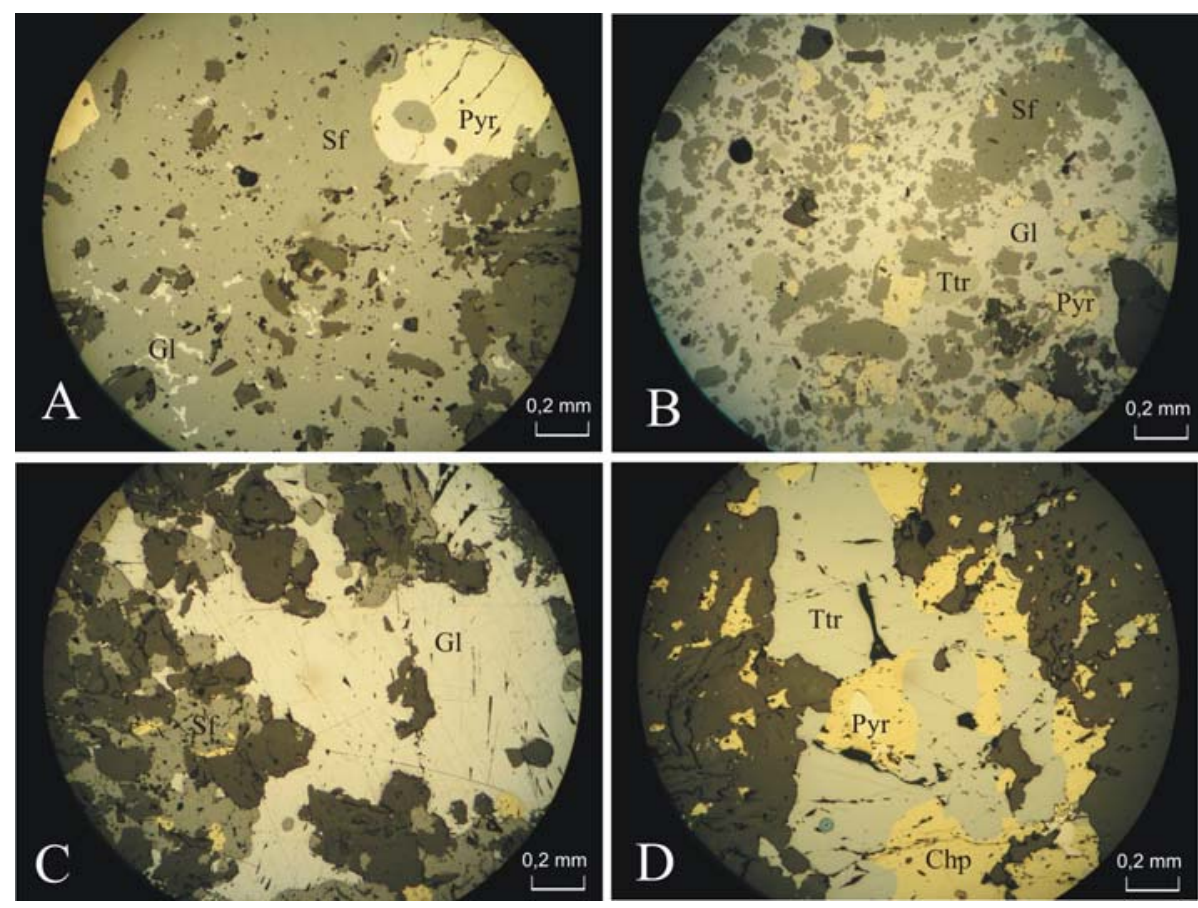

Anh 1. Các khoáng vật quặng mỏ Na Sơn: A - tập hợp hạt lớn sphalerit (Sf) trong có chứa các bao thể galenit tấm nhỏ $(\mathrm{Gl})$ và pyrite khá tự hình (Pyr); B - tập hợp galenit $(\mathrm{Gl})$ trong có chứa các hạt sphalerit

(Sf), tetraedrit (Ttr) và các mảnh pyrit (Pyr); C - tổ hợp galenit (Gl) sphalerit $(\mathrm{Sf})$ và chalcopyrit; $\mathrm{D}$ - tập hợp mọc xen giữa tetraedrit (Ttr), chalcopyrit (Chp) và pyrit (Pyr)

Đặc biệt, trong một số mẫu khoáng tướng được lấy từ đới quặng I còn quan sát thấy sphalerit có hiện tượng tái kết tinh yếu, đôi khi có vết rạn nứt có thể do chúng bị nén ép tạo ra.

Kết quả phân tích thành phần hóa học của sphalerit (bảng 2) cho thấy: $\mathrm{Zn}=62,24-66,01 \%$, $\mathrm{S}=32,45-33,97 \%$, đặc trưng nghèo hàm lượng $\mathrm{Fe}$ $(0,15-4,81 \%)$, Mn (0-0,06\%), Bi (0-0,042\%), In $(0,00-0,0047 \%$, ngoại trừ mẫu KC.540 có In lên tới $0,021 \%)$. Ngược lại, hàm lượng $\mathrm{Cd}$ trong sphalerit ở đây lại tương đối giàu $(0,1-0,5 \%$, trung bình $0,32 \%)$.

Bảng 2. Thành phần của các nguyên tố chủ yếu trong sphalerit vùng mỏ $\mathrm{Na}$ Sơn

\begin{tabular}{|c|c|c|c|c|c|c|c|c|c|c|}
\hline Ng.tố & $\mathrm{Cd}$ & Ga & $S$ & $\mathrm{Fe}$ & $\mathrm{Zn}$ & In & Ge & $\mathrm{Bi}$ & $\mathrm{Mn}$ & Total \\
\hline $\begin{array}{l}\text { Trung } \\
\text { binh }\end{array}$ & 0,32 & 0,01 & 33,04 & 1,84 & 64,63 & 0,00 & 0,00 & 0,01 & 0,02 & 99,87 \\
\hline Min & 0,10 & 0,00 & 32,45 & 0,15 & 62,24 & 0,00 & 0,00 & 0,00 & 0,00 & 98,58 \\
\hline Max & 0,50 & 0,04 & 33,97 & 4,81 & 66,01 & 0,02 & 0,00 & 0,04 & 0,06 & 101,49 \\
\hline
\end{tabular}

Ghi chú: Các kết quả phân tích ở bảng 1 và 2 bằng phương pháp microzon trên máy «Camebax-Micro», người phân tích: Khmennikova O.X., Poxpelova L.N., Nigmatulina E.; Phân tích tại Viện Địa Chất và Khoáng vật học, phân viện Novosibirsk, Viện HLKH Nga. 
Pyrit $\left(\mathrm{FeS}_{2}\right)$ là khoáng vật quặng khá phổ biến ở mỏ Na Sơn, chúng có mặt trong hầu hết các mẫu dưới dạng các ổ nhỏ, đám nhỏ hoặc thành từng hạt nhỏ riêng biệt (ảnh 1; A), mức độ tự hình thể hiện khác nhau. Có hai thế hệ pyrit:

- Pyrit thế hệ 1: là các hạt xâm tán, có kích thước nhỏ $(0,00 \mathrm{nmm})$, đẳng thước, phân bố đồng đều trong phần nền của đá ryolit hoặc microsyenit biến đổi.
- Pyrit thế hệ 2: là các hạt tự hình, kích thước nhiều hạt đạt tới centimét, thường cộng sinh chặt chẽ với sphalerit, galenit và chalcopyrit. Khá nhiều trường hợp quan sát thấy pyrite bị phá hủy gặm mòn và được galenit chen lấp vào.

Thành phần hóa học của pyrit (bảng 3) cho thấy hàm lượng $\mathrm{Fe}=46,02-46,94 \%, \mathrm{~S}=52,17-53,91 \%$, các thành phần khác cần quan tâm như $\mathrm{Ni}(0,02-$ 0,17\%), Co $(0,03-0,46 \%)$.

Bảng 3. Thành phần hóa học cơ bản của pyrit trong vùng mỏ Na Sơn

\begin{tabular}{|c|c|c|c|c|c|c|c|c|c|}
\hline Ng.tố & $\mathrm{Fe}$ & Co & As & $S$ & $\mathrm{Ni}$ & $\mathrm{Cu}$ & $\mathrm{Se}$ & Mo & Tổng \\
\hline Trung bình & 46,45 & 0,13 & 0,01 & 52,83 & 0,08 & 0,03 & 0,00 & 0,01 & 99,54 \\
\hline Min & 46,02 & 0,03 & 0,00 & 52,17 & 0,02 & 0,00 & 0,00 & 0,00 & 98,41 \\
\hline Max & 46,94 & 0,46 & 0,03 & 53,91 & 0,17 & 0,07 & 0,00 & 0,08 & 101,60 \\
\hline
\end{tabular}

Ghi chú: Phân tích bằng phương pháp microzon trên máy «Camebax-Micro», người phân tích: Khmennikova O.X., Poxpelova L.N., Nigmatulina E., Phân tích tại Viện Địa Chất và Khoáng vật học, phân viện Novosibirsk, Viện HLKH Nga.

Chalcopyrit $\left(\mathrm{CuFeS}_{2}\right)$ là khoáng vật khá phổ biến, thường đi kèm với galenit, sphalerit và tetraedrit, chúng tập trung nhiều nhất ở phần ven rìa dưới dạng các ồ, mạch đi cùng với thạch anh. Quan sát dưới kính phản quang cho thấy chalcopyrit chủ yếu tồn tại dưới dạng các hạt toàn tha hình (ảnh 1-D), kích thước theo chiều dài nhiều khi đạt tới $1,5 \mathrm{~cm}$. Những hạt có kích thước nhỏ thường tập hợp thành dải kéo dài dọc theo hướng phân phiến, hoặc xâm tán thưa trong đá. Đôi khi chúng xuất hiện dưới dạng các hạt nhũ tương (emusi) định hướng dọc theo trục tinh thể, là sản phẩm phân hủy dung dịch cứng chalcopyritsphalerit.

Kết quả phân tích thành phần hóa học của chalcopyrit (bảng 4) cho thấy hàm lượng các nguyên tố chính $\mathrm{Cu}=34,42-35,02 \%, \quad \mathrm{Fe}=29,24-$ $30,34 \%, \mathrm{~S}=34,48-35,13$; Các nguyên tố đi kèm trong chalcopyrit với hàm lượng đáng lưu ý gồm có: $\mathrm{Au}(0,003-0,032 \%), \quad \mathrm{Co}(0,002-0,04 \%), \quad \mathrm{Ni}(0,005-$ $0,023 \%), \quad \operatorname{Ag}(0,011-0,017 \%), \quad \operatorname{Mo}(0,044-0,06 \%)$, $\operatorname{Se}(0,015-0,02 \%), \operatorname{Sn}(0,01-0,021 \%)$.

Bảng 4. Thành phần hóa học trung bình (\%) của chalcopyrit mỏ Na Sơn

\begin{tabular}{|c|c|c|c|c|c|c|c|c|c|c|c|c|}
\hline Ng.tố & $\mathrm{Cu}$ & $\mathrm{Fe}$ & $S$ & $\mathrm{Ag}$ & As & $\mathrm{Ni}$ & Sn & $\mathrm{Se}$ & Co & $\mathrm{Au}$ & Mo & Tổng \\
\hline Trung bình & 34,80 & 30,07 & 34,92 & 0,014 & 0,014 & 0,015 & 0,015 & 0,017 & 0,015 & 0,013 & 0,052 & 99,95 \\
\hline Min & 34,42 & 29,24 & 34,48 & 0,011 & 0,00 & 0,005 & 0,010 & 0,015 & 0,002 & 0,003 & 0,044 & 98,23 \\
\hline Max & 35,02 & 30,34 & 35,13 & 0,017 & 0,016 & 0,023 & 0,021 & 0,02 & 0,040 & 0,032 & 0,06 & 100,72 \\
\hline
\end{tabular}

Pyrotin $\left(\mathrm{Fe}_{1-x} S\right)$ là khoáng vật ít phổ biến trong các thân quặng, thường rải rác hiếm khi thấy chúng cụm lại thành tập hợp lớn. Một số mẫu khoáng tướng còn quan sát thấy pyrotin xuất hiện nghèo nàn dưới dạng nhũ tương trong sphalerit. Ngoài ra, ở một số điểm trong đới quặng II còn quan sát thấy chúng cộng sinh với pyrit, chalcopyrit, sphalerit và galenit dưới dạng các tập hợp hạt nhỏ hoặc xâm tán trong đá vây quanh.
Kết quả phân tích thành phần hóa học của pyrotin (bảng 5 ) cho thấy hàm lượng các nguyên tố chính như $\mathrm{Fe}=61,05-61,34 \% ; \mathrm{S}=39,19-39,35 \%$. Các nguyên tố khác có hàm lượng không đáng kể, song cần phải lưu ý về sự có mặt của $\mathrm{Mo}$ $(0,055 \sim 0,1 \%)$ và $\mathrm{Au}$ với hàm lượng đến $0,021 \%$.

Tetraedrit $\left(C u_{12} S b_{4} S_{13}\right)$. Quặng đồng xám là khoáng vật tương đối phổ biến ở mỏ $\mathrm{Na}$ Sơn, gặp 
chúng trong cả mẫu trọng sa nhân tạo lẫn mẫu khoáng tướng (nhất là ở đới quặng II). Tetraeđrit thường có dạng mảnh sắc cạnh, màu xám thép, dòn. Dưới kính hiển vi, có màu xám sáng, ánh bạc, độ phản quang kém hơn galenit, thường tạo thành các bao thể nhỏ trong galenit (ảnh 1D), ngoài ra trong một số mẫu còn gặp các hạt tetraeđrit có kích thước gần $0,2 \mathrm{~mm}$ mọc xen cùng với galenit.

Bảng 5. Thành phần hóa học trung bình $(\%)$ của pyrotin mỏ Na Sơn

\begin{tabular}{|c|c|c|c|c|c|c|c|c|c|}
\hline Ng.tố & $\mathrm{Fe}$ & $S$ & Co & As & $\mathrm{Au}$ & Mo & $\mathrm{Cu}$ & $\mathrm{Ni}$ & Tổng \\
\hline Trung bình & 61,17 & 39,5 & 0,018 & 0 & 0 & 0,058 & 0,053 & 0,036 & 100,84 \\
\hline Min & 61,05 & 39,19 & 0,006 & 0 & 0 & 0,055 & 0,019 & 0,04 & 100,36 \\
\hline Max & 61,34 & 39,35 & 0,033 & 0 & 0,021 & 0,097 & 0,075 & 0,028 & 100,94 \\
\hline
\end{tabular}

Ghi chú: Các mẫu ở bảng 4 và 5 được phân tích bằng phương pháp microzond tại trung tâm phân tích thuộc Viện $Đ \mathrm{C}$ và KV học, phân viện Sibiri, Viện HLKH Nga. Người phân tích Khmennikova O.X.; Poxpelov L.N.; Nigmatulina E.

Kết quả phân tích thành phần hóa học của tetraedrit (bảng O) cho thấy quặng đồng xám ở đây chủ yếu thuộc loại zanbergit (hay tetraedrit giàu $\mathrm{Zn}$ ), hàm lượng $\mathrm{Zn}$ dao động trong khoảng 5$7,36 \%$. Ngoại trừ mẫu $\mathrm{KC} .526$ có hàm lượng $\mathrm{Ag}$ cao $(14,47 \%)$, chúng thuộc loại freibergit hay tetraedrit cao Ag. Các mẫu còn lại có hàm lượng
Ag thấp hơn, thường dao động trong khoảng từ $0,42-5,67 \%$. Hàm lượng $\mathrm{Fe}(0,22-2,58 \%)$ tương đối thấp, vì vậy tetraedrit ở đây chủ yếu có màu xám thép (giàu $\mathrm{Zn}$ ) chứ không phải loại màu đen (giàu $\mathrm{Fe}$ ). Ngoài ra, trong thành phần của tetraedrit cần lưu ý $\mathrm{Te}$ và $\mathrm{Se}$ với hàm lượng tương ứng $(\mathrm{Te}=0,03-0,06 \%),(\mathrm{Se}=0,00-0,02 \%)$.

Bảng 6. Thành phần hóa học trung bình (\%) của tetrahedrit mỏ Na Sơn

\begin{tabular}{|c|c|c|c|c|c|c|c|c|c|c|c|}
\hline KHM & $\mathrm{Cu}$ & As & $\mathrm{Se}$ & $\mathrm{Sb}$ & $\mathrm{Te}$ & $\mathrm{Zn}$ & $\mathrm{Fe}$ & $\mathrm{Ag}$ & $S$ & $\mathrm{~Pb}$ & Total \\
\hline KC.512 & 36,97 & 0,48 & 0,00 & 26,58 & 0,00 & 4,93 & 2,58 & 2,03 & 25,07 & 0,07 & 98,72 \\
\hline KC.524 & 37,64 & 0,00 & 0,00 & 28,34 & 0,00 & 7,33 & 0,72 & 0,42 & 25,02 & 0,08 & 99,55 \\
\hline KC.526 & 27,15 & 0,03 & 0,00 & 25,78 & 0,00 & 5,66 & 1,22 & 14,40 & 23,41 & 0,09 & 97,74 \\
\hline KC.537 & 38,61 & 1,57 & 0,00 & 25,36 & 0,00 & 5,45 & 2,08 & 0,51 & 25,44 & 0,09 & 99,12 \\
\hline NS.08.50 & 33,49 & 0,00 & 0,00 & 28,14 & 0,00 & 6,86 & 0,22 & 5,67 & 24,60 & 0,07 & 99,06 \\
\hline NS.08.58 & 37,39 & 0,60 & 0,00 & 26,77 & 0,00 & 7,36 & 0,30 & 1,21 & 25,44 & 0,09 & 99,16 \\
\hline KC-600 & 29,49 & 0,00 & 0,00 & 27,49 & 0,03 & 6,50 & 0,44 & 8,34 & 23,23 & 0,00 & 95,54 \\
\hline KC-607 & 32,83 & 0,55 & 0,00 & 26,16 & 0,04 & 4,72 & 2,06 & 7,94 & 24,04 & 0,00 & 98,35 \\
\hline KC-602 & 34,27 & 2,49 & 0,02 & 25,40 & 0,03 & 5,29 & 1,91 & 6,36 & 25,36 & 0,00 & 101,13 \\
\hline KC-603 & 31,81 & 0,00 & 0,00 & 28,48 & 0,06 & 6,13 & 0,69 & 8,15 & 24,71 & 0,00 & 100,01 \\
\hline КС-612 & 37,24 & 0,88 & 0,01 & 27,50 & 0,03 & 6,52 & 1,27 & 0,79 & 25,99 & 0,00 & 100,23 \\
\hline Tr. bình & 34,26 & 0,60 & 0,00 & 26,91 & 0,02 & 6,07 & 1,23 & 5,08 & 24,76 & 0,04 & 98,96 \\
\hline $\min$ & 27,15 & 0,00 & 0,00 & 25,36 & 0,00 & 4,72 & 0,22 & 0,42 & 23,23 & 0,00 & 95,54 \\
\hline $\max$ & 38,61 & 2,49 & 0,02 & 28,48 & 0,06 & 7,36 & 2,58 & 14,40 & 25,99 & 0,09 & 101,13 \\
\hline
\end{tabular}

Ghi chú: Phân tích bằng phương pháp microzon trên máy «Camebax-Micro», người phân tích: Khmennikova O.X., Poxpelova L.N., Nigmatulina E.; Phân tích tại Viện Địa Chất và Khoáng vật học, phân viện Novosibirsk, Viện HLKH Nga. 
Arsenopyrit ( $F e A s S$ ) có mặt với số lượng không đáng kể trong các thân quặng ở vùng mỏ $\mathrm{Na}$ Sơn, chúng thường cộng sinh với galenit, sphalerit, tetraedrit và chalcopyrite. Tinh thể thường có dạng hình bán thoi, bình hành hoặc không có hình thù nhất định, kích thước hạt nhỏ nửa tự hình hay tha hình, độ mài nhẵn rất tốt. Ở giai đoạn đầu của quá trình tạo quặng, arsenopyrit thường tồn tại dưới dạng các hạt đơn lẻ, sau đó chúng bị các tập hợp galenit, sphalerit, tetraedrit và chalcopyrit gặm mòn thay thế.

Ngoài các khoáng vật quặng nguyên sinh như đã mô tả ở trên, trong vùng mỏ còn có mặt một số khoáng vật biểu sinh như smitsonit, anglezit,... với số lượng không đáng kể được hình thành do quá trình phong hóa bề mặt của sphalerit, galenit và các khoáng vật nguyên sinh khác... Đặc biệt, khi tiến hành nghiên cứu quặng trên kính hiển vi điện tử quét chúng tôi cũng đã phát hiện thấy sự có mặt của ortit.

\section{4. Đặc điểm phân bố hàm lượng các nguyên tố tạo quặng chính và các nguyên tố đi kèm}

Đánh giá đặc điểm phân bố hàm lượng các nguyên tố tạo quặng chính (kim loại chính) và các nguyên tố đi kèm trong các thân quặng vùng mỏ $\mathrm{Na}$ Sơn, nhằm tìm hiểu quy luật và các dạng tồn tại của chúng, đồng thời có cơ sở để đưa ra các biện pháp thích hợp nhất nhằm thu hồi tối đa nguồn tài nguyên, tăng giá trị kinh tế và đảm bảo an toàn môi trường sinh thái cho vùng mỏ. Để đạt được mục đích nêu trên chúng tôi đã tiến hành phân tích hàm lượng các nguyên tố chính và đi kèm bằng phương pháp XRF với các đối tượng sau: 1- Trong quặng chì kẽm nguyên khai; 2- Trong tinh quặng chì; 3Trong tinh quặng kẽm; 4- Trong đuôi thải. Cách thức tiến hành phân tích theo nhóm đối tượng này có thể giúp phát hiện sự có mặt hay vắng mặt của các nguyên tố, nhóm nguyên tố qua mỗi công đoạn cũng như các mối quan hệ cộng sinh giữa chúng với nhau...

Các nguyên tố chính. Theo kết quả phân tích quặng nguyên khai (bảng 7) bằng phương pháp XRF cho chúng ta thấy hàm lượng $\mathrm{PbO}$ dao động trong một khoảng khá rộng từ 0,344 đến $32,43 \%$; ngược lại hàm lượng $\mathrm{ZnO}$ lại dao động trong khoảng hẹp từ $0,14-2,97 \%$. Kết quả phân tích quang phổ hấp thụ nguyên tử cho thấy: hàm lượng kim loại $\mathrm{Pb}(1,11-70 \%)$, Zn (3,1-42\%). Kết quả phân tích TD-MS (Thermal desorption-Mass spectrometric), hàm lượng kim loại $\mathrm{Pb}(1,69$ $64,9 \%)$, hàm lượng $\mathrm{Zn}(0,6-45 \%)$. Những số liệu phân tích nêu ra ở trên, một lần nữa cho chúng ta thấy hàm lượng của $\mathrm{Pb}$ và $\mathrm{Zn}$ ở mỏ $\mathrm{Na}$ Sơn vào loại tương đối giàu.

Bảng 7. Thành phần hóa học (\%tl) của quặng nguyên khai (quăng và đá chứa quặng) mỏ Na Sơn, phân tích bằng phương pháp XRF

\begin{tabular}{|c|c|c|c|c|}
\hline KHM & KC.526 & NS.08.41 & NS.08.49 & NS.08.54 \\
\hline Loại quặng & $\begin{array}{l}\text { Quặng galenit- } \\
\text { chal lò } 3\end{array}$ & $\begin{array}{l}\text { Quặng Pb-Zn-Cu } \\
\text { cos } 580\end{array}$ & $\begin{array}{c}\text { Quặng Pb-Zn phân dải } \\
\text { Lò } 2\end{array}$ & $\begin{array}{l}\text { Mạch felspat có } \\
\text { chal Lò } 4\end{array}$ \\
\hline $\mathrm{SO}_{3}$ & 11,23 & 2,516 & 5,400 & 1,830 \\
\hline $\mathrm{ZnO}$ & 2,97 & 0,196 & 2,133 & 0,137 \\
\hline $\mathrm{PbO}$ & 32,43 & & 15,370 & 0,344 \\
\hline $\mathrm{SiO}_{2}$ & 29,43 & 7,248 & 47,790 & 51,780 \\
\hline $\mathrm{CaO}$ & 0,29 & 30,400 & 1,270 & 1,833 \\
\hline $\mathrm{TiO}_{2}$ & 0,34 & 0,147 & 0,361 & 0,494 \\
\hline $\mathrm{Al}_{2} \mathrm{O}_{3}$ & 7,57 & 2,940 & 9,238 & 12,290 \\
\hline $\mathrm{Fe}_{2} \mathrm{O}_{3}$ & 0,57 & 24,150 & 1,446 & 3,240 \\
\hline $\mathrm{MgO}$ & 0,25 & 7,459 & 0,494 & 1,180 \\
\hline $\mathrm{MnO}$ & 0,025 & 2,027 & 0,090 & 0,174 \\
\hline $\mathrm{Na}_{2} \mathrm{O}$ & 0,222 & & 0,148 & 0,109 \\
\hline $\mathrm{CuO}$ & 0,163 & & 0,094 & 1,026 \\
\hline $\mathrm{K}_{2} \mathrm{O}$ & 6,164 & 1,782 & 8,158 & 8,983 \\
\hline
\end{tabular}


Các nguyên tố đi kèm. Sự tập trung của các nguyên tố có ích đi kèm luôn phụ thuộc vào hành vi địa hóa của chúng và điều kiện địa chất hình thành các mỏ khoáng. Các mỏ kim loại màu là nguồn duy nhất để lấy các nguyên tố đi kèm rất có giá trị như $\mathrm{Cd}, \mathrm{In}, \mathrm{Se}, \mathrm{Te}, \mathrm{Re}, \mathrm{Sc}, \mathrm{Tl}, \mathrm{Ge}, \ldots$ và sự có mặt của chúng trong quặng nhiều khi lại có giá trị kinh tế vượt xa cả các nguyên tố chính.

Cho đến nay, các tài liệu phân tích về hàm lượng các nguyên tố đi kèm trong các mỏ chì-kẽm ở Đông Bắc Việt Nam nói riêng và Việt Nam nói chung còn rất hạn chế, vì vậy việc nghiên cứu các nguyên tố có ích đi kèm hầu hết chưa có hệ thống. Trong công trình này, chúng tôi đã tiến hành phân tích mẫu các loại bằng nhiều phương pháp khác nhau để có được một bộ kết quả hoàn chỉnh về các nguyên tố đi kèm với quặng chì-kẽm ở vùng mỏ $\mathrm{Na}$ Sơn. Các kết quả phân tích được dẫn ra (bảng $8,9)$ thể hiện hàm lượng của các nguyên tố đi kèm trong các đối tượng lấy mẫu khác nhau. Dưới đây là những diễn giải các kết quả đó:

- Nguyên tố $\mathrm{Cu}$, hàm lượng của $\mathrm{Cu}$ trong quặng chì-kẽm mỏ Na Sơn có giá trị cao nhất so với các nguyên tố khác, kể cả ở quặng nguyên khai lẫn trong các tinh quặng chì-kẽm. Xác định bằng phương pháp Quang phổ hấp thụ nguyên tử (QPHTNT) cho thấy $\mathrm{Cu}$ dao động trong một khoảng khá rộng từ $>0.01 \%$ trong đuôi thải đến
$2,02 \%$ trong tinh quặng chì $(\mathrm{TB}-0.84 \%, \mathrm{n}=10)$ và bằng phương pháp $\mathrm{TD}-\mathrm{MS}$ cho thấy $\mathrm{Cu}$ dao động từ 192-21400ppm (TB-8430.86ppm, n=7). Hàm lượng $\mathrm{Cu}$ tập trung cao nhất trong tinh quặng chì $(1 \sim 3 \%)$, thứ đến là trong tinh quặng kẽm (xấp xỉ 1$1,5 \%)$. Đối với mỏ $\mathrm{Na}$ Sơn, ngoài $\mathrm{Pb}$ và $\mathrm{Zn}$ thì $\mathrm{Cu}$ là một đối tượng rất cần được quan tâm.

- Nguyên tố $C d$, hàm lượng của $\mathrm{Cd}$ ở vùng mỏ Na Sơn khá cao, $\mathrm{Cd}=66-1450 \mathrm{ppm}$ (TB-578.71ppm, phương pháp TD-MS), đặc biệt $\mathrm{Cd}$ trong tinh quặng $\mathrm{Zn}$ có hàm lượng đạt đến 1090 ppm, chỉ kém chút ít so với $\mathrm{Cd}$ trong tinh quặng $\mathrm{Zn}$ ở mỏ Làng Hích (mỏ có hàm lượng $\mathrm{Cd}$ cao nhất ở Việt Nam) [8-10], Cd có mối tương quan thuận rất rõ nét với $\mathrm{Zn}$. Hàm lượng $\mathrm{Cd}$ giảm cùng với sự giảm dần hàm lượng kẽm từ trong tinh quặng kẽm qua quặng nguyên khai, tinh quặng chì đến đuôi thải và dao động trong khoảng $0.11-0.005 \%$ (TB- $0.04 \%$, phương pháp QPHTNT). Dạng tồn tại chủ yếu của $\mathrm{Cd}$ là thay thế đồng hình với $\mathrm{Zn}$ và $\mathrm{Fe}$ trong sphalerit.

Tỷ số hàm lượng $\mathrm{Zn} / \mathrm{Cd}$ (bảng 8 ) trong sphalerit của đới quặng I rất cao $(381,82-700)$, còn ở đới quặng II có giá trị thấp hơn $(87,5-204,44)$. Theo Ivanov V.V. $[5,6]$ tỷ số hàm lượng $\mathrm{Zn} / \mathrm{Cd}$ thay đổi từ dưới lên và tăng ở phần trên thân quặng. Như vậy, nếu xét theo trường hợp này cho thấy đới quặng I đã bị bóc mòn tới phần thấp, còn đới quặng II mới được lộ ra ở phần trên thân quặng.

Bảng 8. Hàm lượng các nguyên tố chính và đi kèm (\%) trong quặng chì-kẽm mỏ Na Sơn phân tích bằng phương pháp QPHTNT tại CHLB Nga

\begin{tabular}{|c|c|c|c|c|c|c|c|c|c|c|}
\hline STT & $\mathrm{KHM}$ & As & $\mathrm{Pb}$ & $\mathrm{Cd}$ & $\mathrm{Cu}$ & $\mathrm{Fe}$ & $\mathrm{Zn}$ & $\mathrm{Bi}, \mathrm{Ga}$ & $\mathrm{Zn} / \mathrm{Pb}$ & $\mathrm{Zn} / \mathrm{Cd}$ \\
\hline 1 & KC.501 & $<0,01$ & 2,1 & 0,11 & 0,078 & 6,1 & 42 & $<0,001$ & 20 & 381,82 \\
\hline 2 & KC.506 & $<0,01$ & 1,11 & 0,065 & 0,005 & 4,3 & 39 & $<0,001$ & 31,14 & 600 \\
\hline 3 & NS08.40 & $<0,01$ & 2,7 & 0,005 & 0,016 & 6,4 & 3,1 & $<0,001$ & 1,15 & 620 \\
\hline 4 & NS08.50 & $<0,01$ & 14 & 0,005 & 0,30 & 1,4 & 3,5 & $<0,001$ & 0,25 & 700 \\
\hline 5 & NS08.56 & $<0,01$ & $64-65$ & 0,049 & 1,19 & 1,75 & 8,9 & - & 0,14 & 181,63 \\
\hline 6 & NS08.57 & $<0,01$ & 18,5 & 0,092 & 1,63 & 6,02 & 17 & $<0,001$ & 0,92 & 184,78 \\
\hline 7 & KC.512 & $<0,01$ & 28 & 0,045 & 1,92 & 3,7 & 8,9 & $<0,001$ & 0,32 & 197,78 \\
\hline 8 & KC.514 & $<0,01$ & 0,10 & 0,0008 & 1,13 & 1,7 & 0,070 & $<0,001$ & 0,7 & 87,50 \\
\hline 9 & KC.526 & $<0,01$ & 46 & 0,019 & 0,15 & 0,21 & 3,1 & $<0,001$ & 0,067 & 163,16 \\
\hline 10 & KC.547 & $<0,01$ & $69-70$ & 0,045 & 2,02 & 1,17 & 9,2 & - & 0,13 & 204,44 \\
\hline
\end{tabular}

Chú giải: 1-4 các mẫu đới quặng I; 5-10 các mẫu đới quặng II 
Bảng 9. Hàm lượng các nguyên tố chính và đi kèm (ppm) trong quặng chì-kẽm mỏ Na Sơn phân tích bằng phương pháp TD-MS tại Cục Địa chất Nhật Bản

\begin{tabular}{|c|c|c|c|c|c|c|c|c|}
\hline KHM & NS.08-40 & NS.08-40 & NS.08-50 & KC.501 & KC.512 & NS.08-46 & NS.08-47 & \\
\hline $\begin{array}{l}\text { Loại } \\
\text { mẫu }\end{array}$ & $\begin{array}{l}\text { Quắng Pb-Zn } \\
\text { (đới quặng I) }\end{array}$ & $\begin{array}{l}\text { Quặng Pb- } \\
\text { Zn (đới } \\
\text { quặng I) }\end{array}$ & $\begin{array}{l}\text { Quặng } \\
\text { Pb (đới } \\
\text { quặng I) }\end{array}$ & $\begin{array}{l}\text { Quặng Sph. } \\
\text { đặc xít (đới } \\
\text { quặng I) }\end{array}$ & $\begin{array}{c}\text { Quặng } \\
\text { Gale. lò } 4 \\
\text { (đới quặng II) }\end{array}$ & $\begin{array}{l}\text { Tinh } \\
\text { quặng } \\
\text { Pb }\end{array}$ & $\begin{array}{l}\text { Tinh quặng } \\
\text { Zn }\end{array}$ & $\begin{array}{c}\text { TB } \\
(n=7)\end{array}$ \\
\hline In & 1,9 & 3,2 & 0,7 & 31,5 & 1 & 2,1 & 3,8 & 2,12 \\
\hline Sn & 7 & 13 & 12 & 46 & 11 & 6 & 11 & 15,14 \\
\hline $\mathrm{Cd}$ & 105 & 163 & 66 & 1450 & 539 & 638 & 1090 & 578,71 \\
\hline $\mathrm{Zn}$ & 31400 & 46200 & 5980 & 450000 & 89300 & 86400 & 153000 & 123183 \\
\hline $\mathrm{Pb}$ & 23700 & 102000 & 145000 & 16900 & 292000 & 649000 & 191000 & 202800 \\
\hline $\mathrm{Cu}$ & 192 & 273 & 3290 & 961 & 21400 & 14300 & 18600 & 8430.86 \\
\hline $\mathrm{Ni}$ & 167 & 395 & 32 & 74 & 247 & 80 & 240 & 176,43 \\
\hline $\mathrm{Ag}$ & 10,0 & 27,1 & 123,0 & 17,5 & 149,0 & 130,0 & 173,0 & 89,94 \\
\hline Co & 79,4 & 138,0 & 55,7 & 50,2 & 211,0 & 229,0 & $>500$ & 127,22 \\
\hline Mo & 15,2 & 29,0 & 257,0 & 18,0 & 3870.0 & 245,0 & 1650,0 & 869,17 \\
\hline $\mathrm{Sb}$ & 10,8 & 29,6 & 53,0 & 22,2 & 323,0 & 263,0 & 89,3 & 112,99 \\
\hline As & 64,7 & 76,7 & 63,9 & 46,6 & 281,0 & 62,9 & 146,0 & 105,97 \\
\hline $\mathrm{Bi}$ & 1,0 & 3,1 & 1,1 & 2,3 & 0,6 & 10,3 & 7,8 & 3,74 \\
\hline $\mathrm{Se}$ & 1,7 & 2,3 & 2,6 & 9,8 & 2,7 & 3,2 & 5,1 & 3,91 \\
\hline $\mathrm{La}$ & 30,6 & 64,7 & 245 & 6,1 & 67 & 56,5 & 211 & 97,27 \\
\hline $\mathrm{Ce}$ & 59,1 & 120 & 454 & 12,3 & 162 & 99,4 & 460 & 195,26 \\
\hline $\operatorname{Pr}$ & 7,1 & 13,8 & 56,2 & 1,5 & 20,8 & 13,5 & 58,3 & 24,46 \\
\hline $\mathrm{Nd}$ & 30,7 & 45,3 & 186 & 5,4 & 71,4 & 45,2 & 198 & 83,14 \\
\hline $\mathrm{Sm}$ & 4,9 & 8,1 & 32,3 & 1 & 12,5 & 8 & 34 & 14,40 \\
\hline $\mathrm{Eu}$ & 1,13 & 1,68 & 2,13 & 0,21 & 2,68 & 0,93 & 4,58 & 1,91 \\
\hline $\mathrm{Gd}$ & 5,9 & 8,6 & 33,8 & 1,2 & 12,2 & 8,2 & 34,1 & 14,86 \\
\hline $\mathrm{Tb}$ & 0,9 & 1,3 & 5,2 & 0,2 & 1,8 & 1,3 & 5,2 & 2,27 \\
\hline Dy & 4,3 & 5,7 & 25,7 & 0,9 & 8,9 & 6,7 & 25,7 & 11,13 \\
\hline $\mathrm{Ho}$ & 0,8 & 1,1 & 5,9 & 0,2 & 2 & 1,6 & 5,8 & 2,49 \\
\hline $\mathrm{Tm}$ & 0,3 & 0,3 & 2,1 & 0,1 & 0,7 & 0,6 & 2,1 & 0,89 \\
\hline $\mathrm{Yb}$ & 1,6 & 1,5 & 12,6 & 0,3 & 4,5 & 3,6 & 11,7 & 5,11 \\
\hline $\mathrm{Lu}$ & 0,2 & 0,2 & 1,7 & $<0,1$ & 0,6 & 0,5 & 1,5 & 0,78 \\
\hline$Y$ & 22,5 & 32,5 & 131 & 5,7 & 46,2 & 41,5 & 136 & 59,34 \\
\hline $\mathrm{Ga}$ & 18,4 & 31,9 & 37,2 & 36,8 & 48,1 & 4,3 & 20,2 & 28,13 \\
\hline $\mathrm{Ge}$ & 0,1 & 0,3 & 0,6 & 8,9 & 0,3 & 0,2 & 0,6 & 1,57 \\
\hline $\mathrm{Te}$ & 0,1 & 0,2 & 0,2 & $<0,1$ & $<0,1$ & 0,1 & $<0,1$ & 0,15 \\
\hline
\end{tabular}

Ngoài sphalerit là khoáng vật chính chứa $\mathrm{Cd}$, ở mỏ $\mathrm{Na}$ Sơn cũng cần quan tâm đến $\mathrm{Cd}$ có mặt trong thành phần của galenit: 539ppm trong quặng chì nguyên khai dạng đặc xít; 638ppm trong tinh quặng chì (bảng 9).
- Nguyên tố Ag. Ở khu mỏ Na Sơn, hàm lượng Ag có giá trị khác nhau do 2 phương pháp phân tích như sau: Phương pháp XRF cho giá trị $\mathrm{Ag}=$ 270-720 ppm; Phương pháp TD-MS cho giá trị $\mathrm{Ag}=10-173 \mathrm{ppm}$ (TB-89.94ppm). Tuy nhiên, đối 
với phương pháp TD-MS, độ nhạy với riêng nguyên tố $\mathrm{Ag}$ là không cao, vì vậy chúng tôi đã tiến hành phân tích $\mathrm{Ag}$ bằng các phương pháp QPHTNT để khẳng định chắc chắn hơn hàm lượng $\mathrm{Ag}$ trong quặng chì kẽm của vùng mỏ.

Kết quả cho thấy trong quặng chì-kẽm Na Sơn có hàm lượng $\mathrm{Ag}$ khá cao, tăng dần theo sự có mặt nhiều hay ít của galenit: ở đới quặng I, sphalerit chiếm ưu thế hơn galenit, $\mathrm{Ag}$ có hàm lượng thay đổi từ 10-123ppm. Ngược lại, ở đới quặng II với galenit chiếm ưu thế, Ag lại có hàm lượng lên đến 149 ppm (bảng 9). Ngoài ra, chúng ta còn thấy hàm lượng $\mathrm{Ag}$ có giá trị tăng dần cùng với hàm lượng $\mathrm{Pb}$, từ thấp nhất trong đuôi thải $(3,5-10 \mathrm{ppm})$ đến quặng nguyên khai (40-100 ppm). Những dẫn chứng nêu trên cho thấy mối liên kết cộng sinh giữa chì và bạc ở vùng mỏ $\mathrm{Na}$ Sơn khá vững chắc. Song cũng cần lưu ý rằng trong tinh quặng kẽm, sự có mặt của $\mathrm{Ag}$ với hàm lượng đáng kể (137ppm) có thể là nguyên nhân về sự có mặt của pha sulfit bạc (như argentit?) cùng tồn tại và chúng cùng được lấy ra trong quá trình tuyển luyện.

- Nguyên tố In, hàm lượng In trong quặng chìkẽm ở mỏ Na Sơn khá thấp. Ở đới quặng I, In thường có giá trị cao hơn $(0,7-31,5 \mathrm{ppm})$ so với đới quặng II (quanh giá trị $\sim 1 \mathrm{ppm}$ ), ngay cả trong tinh quặng $\mathrm{Zn}$ cho thấy In cũng có giá trị cao hơn (3,8ppm) so với $(2,1 \mathrm{ppm})$ trong tinh quặng $\mathrm{Pb}$ (bảng 9). Ngoài ra còn thấy khá rõ In có xu hướng dảm dần từ tinh quặng kẽm xuống tinh quặng chì đến quặng nguyên khai và cuối cùng thấp nhất ở đuôi thải. Qua dẫn liệu trên cho thấy In chủ yếu nằm trong sphalerit, điều đó cũng phù hợp với đới quặng I của mỏ $\mathrm{Na}$ Sơn với ưu thế chủ yếu là sphalerit.

Theo một số nhà nghiên cứu [4-6] cho thấy In trong sphalerit giai đoạn sớm tăng cao cùng với $\mathrm{Fe}$ và hàm lượng của chúng tăng theo độ sâu liên quan với sự tăng của tỷ số $\mathrm{Zn} / \mathrm{Pb}$. Các số liệu tính toán (bảng 8 ) cho thấy ở đới quặng I, tỉ số này có giá trị $(0,25-31,14)$ cao hơn đới quặng II $(0,067-0,92)$, xét theo mối tương quan giữa In với tỉ số này một lần nữa thêm bằng chứng cho nhận định về sự bóc mòn của đới quặng $\mathrm{I}$ và còn triển vọng dưới sâu của đới quặng II ở vùng mỏ $\mathrm{Na}$ Sơn.

- Nguyên tố Mo, trái ngược lại với In, hàm lượng Mo trong mỏ Na Sơn lại có giá trị khá cao. Hiện tại chưa tìm thấy khoáng vật độc lập của Mo, song chúng ta thấy trong đới quặng II nơi có galenit và các sulfur khác chiếm ưu thế, Mo có hàm lượng rất cao $(3870 \mathrm{ppm})$ và có $\mathrm{xu}$ hướng tương quan thuận với $\mathrm{Pb}$ khá rõ nét ngay cả trong đuôi thải (11-90ppm), trong quặng nguyên khai ( 60-110ppm) lẫn tinh quặng chì (110-800ppm). Rất có thể Mo nằm trong khoáng vật chứa $\mathrm{Pb}$ và $\mathrm{Cu}$ (galenit và chalcopyrite). Tuy nhiên cũng cần lưu ý về sự tăng cao hàm lượng của Mo trong tinh quặng kẽm (1650ppm).

- Nguyên tố Sb. Là nguyên tố thường liên quan đến các mỏ sulfur nhiệt dịch nhiệt độ thấp và có vị trí xa các các trung tâm phân dị các dung dịch nhiệt dịch. Trong mỏ $\mathrm{Na}$ Sơn, hàm lượng Sb trong quặng thường không cao, chúng dao động trong khoảng 10,8-89,3 ppm (TB-113ppm, phân tích bằng phương pháp TD-MS), cá biệt hai mẫu có hàm lượng cao là $\mathrm{KC} .512(\mathrm{Sb}=263 \mathrm{ppm})$ và $\mathrm{NS} .08-46$ $(\mathrm{Sb}=323 \mathrm{ppm})$. Mặc dù ở các mức hàm lượng khác nhau nhưng $\mathrm{Sb}$ đều tuân theo quy luật tỉ lệ thuận với hàm lượng $\mathrm{Pb}$, đây cũng có thể là nét đặc trưng đối với các mỏ $\mathrm{Pb}-\mathrm{Zn}$ ở đông bắc $\mathrm{VN}$. Sự có mặt của $\mathrm{Sb}$ trong hầu hết các kết quả phân tích phản ánh quá trình tạo quặng đã xảy ra ở điều kiện nhiệt độ trung bình đến thấp ở mỏ đang nghiên cứu.

- Nguyên tố Bi. Hàm lượng của Bi trong quặng của mỏ Na Sơn không cao. Ở đới quặng I $(\mathrm{Bi}=1$ $2,3 \mathrm{ppm})$, đới quặng II ( $\mathrm{Bi}=0,6 \mathrm{ppm})$, song cần lưu ý trong tinh quặng $\mathrm{Pb}$ chúng có giá trị $(\mathrm{Bi}=10,3 \mathrm{ppm})$ cao hơn trong tinh quặng $\mathrm{Zn}(\mathrm{Bi}=7,8 \mathrm{ppm})$. Trong mỏ không tìm thấy khoáng vật độc lập của $\mathrm{Bi}$ nhưng qua phân tích với hàm lượng như đã nêu có thể Bi tồn tại một lượng nhỏ chủ yếu trong các khoáng vật sulfur của $\mathrm{Pb}, \mathrm{As}, \mathrm{Cu}, \mathrm{Fe}$ [12].

- Hàm lương các nguyên tố $\mathrm{Sn}, \mathrm{Ga}, \mathrm{Ge}, \mathrm{Se}, \mathrm{Te}$ nhìn chung hầu hết không đặc trưng cho mỏ quặng chì-kẽm Na Sơn, chúng đều có giá trị thấp: Sn-646ppm (TB-15.14ppm - phân tích bằng pp TDMS); Ga nhỏ hơn 0.001\% (QPHTNT), Ga-4.348.1ppm (TB-28.13ppm, TD-MS); Ge- 0.1-8.9ppm (TB-1.57ppm, TD-MS); Se-1.7-9.8ppm (TB3.91ppm, $\mathrm{n}=7$, TD-MS); Te nhỏ hơn 0.1-0.2ppm (TD-MS). Mặc dù các nguyên tố kể trên đều có giá trị hàm lượng thấp, song riêng với $\mathrm{Ga}, \mathrm{Te}$ và $\mathrm{Ge}$ trong mỏ Na Sơn lại có hàm lượng cao hơn so với các mỏ Chợ Đồn, Chợ Điền và Làng Hích và đây cũng là nét khác biệt cần được quan tâm nghiên cứu các nguyên tố trên ở mỏ $\mathrm{Na}$ Sơn.

Như vậy, qua các kết quả phân tích ở các mẫu lấy theo các công đoạn khác nhau (từ mẫu nguyên khai, mẫu chọn trước khi tuyển, mẫu nghiền qua máy đến các tinh quặng và đuôi thải,...) cho thấy 
trong quặng vùng mỏ Na Sơn, ngoài các nguyên tố chính có hàm lượng cao $(\mathrm{Pb}, \mathrm{Zn})$, trong quặng còn giàu các nguyên tố đi kèm như $\mathrm{Cu}, \mathrm{Cd}, \mathrm{Ag}, \mathrm{In}, \mathrm{Mo}$, $\mathrm{Sb}$ và một lượng đáng kể các nguyên tố $\mathrm{Ga}, \mathrm{Re}, \mathrm{Rb}$...

- Nhóm đất hiếm. Kết quả phân tích hàm lượng các nguyên tố nhóm TR nhìn chung đều thấp (xem bảng 9), nhất là nhóm đất hiếm nặng, chỉ dao động trong khoảng 0,89ppm (Tm) đến 59,34ppm (Y). Tuy nhiên ở nhóm đất hiếm nhẹ lại có hàm lượng khá cao: Ce (195,26ppm), La (97,27ppm) và $\mathrm{Nd}$ $(83,14 \mathrm{ppm})$, đặc biệt là trong đuôi thải chúng có giá trị vượt trội hơn hẳn: $\mathrm{Ce}(412,33 \mathrm{ppm})$, La (189ppm), Nd (140,67ppm),...(bảng 10).

Bảng 10. Hàm lượng các nguyên tố đất hiếm (REE) trong quặng nguyên khai và trong các mẫu ở các giai đoạn khác nhau

\begin{tabular}{|c|c|c|c|c|c|}
\hline Các ng. tố, ppm & $\begin{array}{l}\text { Mẫu tại các lò } \\
\text { (nguyên khai) }\end{array}$ & $\begin{array}{l}\text { Mẫu trước khi } \\
\text { tuyển (đã chọn) }\end{array}$ & Tinh quặng Pb & Tinh quặng Zn & Đuôi thải sau máy \\
\hline $\mathrm{La}$ & 86,94 & 190,00 & 39,73 & 106,80 & 189,00 \\
\hline $\mathrm{Ce}$ & 157,24 & 407,67 & 79,95 & 248,30 & 412,33 \\
\hline $\operatorname{Pr}$ & 19,67 & 40,43 & 8,78 & 30,17 & 41,27 \\
\hline $\mathrm{Nd}$ & 67,38 & 137,33 & 29,80 & 104,17 & 140,67 \\
\hline $\mathrm{Sm}$ & 12,23 & 24,30 & 5,60 & 19,07 & 25,17 \\
\hline $\mathrm{Eu}$ & 1,81 & 2,47 & 0,75 & 2,53 & 2,56 \\
\hline $\mathrm{Gd}$ & 13,47 & 21,30 & 5,43 & 18,23 & 21,10 \\
\hline $\mathrm{Tb}$ & 1,82 & 3,27 & 0,88 & 2,77 & 3,13 \\
\hline Dy & 9,17 & 19,70 & 5,18 & 14,87 & 18,97 \\
\hline Ho & 1,78 & 3,87 & 1,08 & 3,17 & 3,80 \\
\hline $\mathrm{Er}$ & 4,75 & 10,67 & 3,05 & 8,53 & 10,47 \\
\hline $\mathrm{Tm}$ & 0,67 & 1,50 & 0,43 & 1,13 & 1,53 \\
\hline $\mathrm{Yb}$ & 3,81 & 8,57 & 2,48 & 6,47 & 8,90 \\
\hline Lu & 0,50 & 1,20 & 0,33 & 0,83 & 1,27 \\
\hline LREE & 345,27 & 802,20 & 164,60 & 511,03 & 810,99 \\
\hline HREE & 35,97 & 70,07 & 18,83 & 56,00 & 69,17 \\
\hline $\mathrm{R} 2 \mathrm{O} 3$ & 381,23 & 872,27 & 183,43 & 567,03 & 880,16 \\
\hline
\end{tabular}

Hàm lượng cao của nhóm đất hiếm nhẹ trong đuôi thải có thể giải thích là do sự có mặt của ortit còn lại trong quá trình tuyển nổi vì chúng không

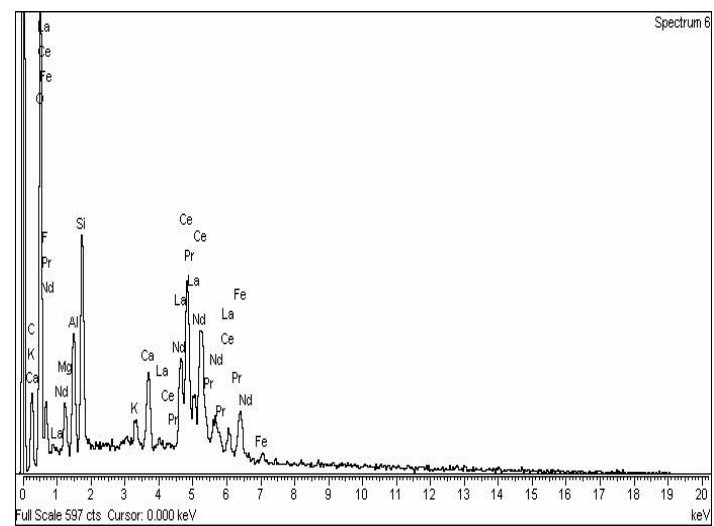

được lọc ra cùng các tinh quặng chì và kẽm (ảnh 7 và hàm lượng REE thực hiện trên kính hiển vi điện tư quét).

Anh 7. Hình ảnh và thành phần hóa học của ortit quan sát trên kính hiển vi điện tử quét.

Mẫu NS-08-50. Khoáng vật màu sáng trắng là ortit 
Theo các báo cáo địa chất về tìm-kiếm thăm dò mỏ chì-kẽm trước đây [2-4] cho rằng vùng mỏ $\mathrm{Na}$ Sơn rất có triển vọng về nguyên tố $\mathrm{TR}$, song lại chưa xác định được nguồn gốc và dạng tồn tại của chúng.

Với kết quả nghiên cứu của chúng tôi cho thấy khoáng vật orit có mặt trong quặng của mỏ $\mathrm{Na}$ Sơn, chính chúng là nguyên nhân dẫn đến nhóm đất hiếm nhẹ có hàm lượng cao, đây là một trong những phát hiện mới làm sáng tỏ sự có mặt các nguyên tố đất hiếm trong khu vực nghiên cứu, vì thế ngoài các nguyên tố đi kèm có giá trị như đã trình bày ở trên thì chính khoáng vật ortit chứa nhóm nguyên tố này cũng cần được quan tâm.

\section{Một số nhận định và kết luận}

\subsection{Về quy luật phân bố quặng}

Trong đó đới quặng I chủ yếu gặp tụ khoáng sphalerit đặc xít với ít hợp phần của galenit, chalcopyrit và các sulfur khác. Đới quặng II chủ yếu gặp tụ khoáng galenit đặc xít với ít hợp phần của sphalerit, chalcopyrit và các sulfur đa kim khác.

Nhìn chung ở cả hai đới quặng đều có thành phần khoáng vật quặng tương tự nhau, chỉ khác nhau về hàm lượng khoáng vật, nguyên tố kim loại quặng.

Theo không gian, quặng hóa phân bố theo quy luật sau:

- Các đới quặng có sự biến đổi tương quan giữa loại quặng và sự giảm hàm lượng kẽm, tăng hàm lượng chì với sự gia tăng lượng đá phun trào, á phun trào.

- Tổng hàm lượng chì - kẽm giảm cùng với sự gia tăng lượng sulfur khác.

- Đới quặng I bị khống chế bởi yếu tố thạch học địa tầng. Đới quặng II quan sát thấy quặng thường nằm nơi giao nhau của hệ thống đứt gãy $\mathrm{TB}$ - $\mathrm{DN}$ và á kinh tuyến, trong các đới phá hủy, đới khe nứt bong lớp (phần lớp bị uốn cong), quặng bị khống chế bởi yếu tố cấu trúc.

- Sự biến đổi hàm lượng khoáng vật quặng phản ánh rõ sự ảnh hưởng của chúng bởi các pha xâm nhập - tăng cường dung dịch quặng cho các khu vực có điều kiện tích tụ thuận lợi.

Theo thời gian, các kết qủa phân tích mẫu khoáng tướng cho thấy: Trong quặng thường quan sát thấy hiện tượng các khoáng vật hình thành ở giai đoạn sớm (magnetit, pyrite...) bị thay thế bởi các khoáng vật khác muộn hơn, hiện tượng trên cho phép nhận định magnetit và các sulfur sắt thuộc giai đọan tích tụ sớm, sau đó là giai đọan tích tụ kẽm (chì), đồng, bạc và giai đọan sau là chì (kẽm), đồng, bạc,... Quá trình trên thể hiện sự tăng cường vật chất cho dung dịch quặng trong quá trình vận hành và trao đổi chất.

\subsection{Về cơ chế thành tạo quặng}

Nhìn chung quặng ở mỏ Na Sơn có cấu tạo rất đa dạng, như: xâm tán, ổ, thấu kính và lấp đầy các khe nứt. Ranh giới thân quặng với đá vây quanh lồi lõm, gồ ghề, trong thân quặng còn quan sát thấy chúng có chứa các mảnh tù của đá vây quanh như syenit, microsyenit thạch anh biotit, microgranit felspat kiềm...., rõ nhất là ở đới quặng II. Những đặc điểm quặng hóa nêu trên cho thấy khoáng hóa chì-kẽm của mỏ Na Sơn được thành tạo trong giai đoạn nhiệt dịch có liên quan chặt chẽ với các pha xâm nhập nông của phức hệ granitoit á núi lửa Tòng Bá.

Các đá vụn núi lửa bị biến đổi có chứa một lượng carbonat là môi trường thuận lợi cho dung dịch nhiệt dịch trao đổi thay thế, thấm lọc trong quá trình tạo quặng $\mathrm{Pb}-\mathrm{Zn}$ (đới quặng I).

Ngoài ra, Hệ thống đứt gãy TB-ĐN, các đới phá hủy kiến tạo giữ vai trò kênh dẫn đồng thời cũng là không gian thuận lợi nhất cho dung dịch nhiệt dịch di chuyển và tập trung.

Nhìn chung ở cả hai đới quặng I và II gần như có cùng một tổ hợp địa hoá gồm các nguyên tố tạo quặng chính: $\mathrm{Pb}-\mathrm{Zn}-\mathrm{Ag}-\mathrm{Cu}-\mathrm{Cd}$. Song giữa hai đới quặng cũng có sự khác biệt nhau:

Đới quặng I nằm trong đá trầm tích núi lửa lục nguyên-carbonat xen phun trào bị biến chất, thân quặng có dạng vỉa, thấu kính, mạch khớp đều với đá vây quanh. Quặng có cấu tạo dải, xâm tán, kiến trúc sót, gặm mòn đặc trưng cho kiểu nguồn gốc nhiệt dịch trao đổi-thay thế.

Đới quặng II chủ yếu nằm trong đới phá hủy kiến tạo, ngoài kiểu thân quặng dạng mạch dọc theo đới dăm kết còn phát triển dọc theo khe nứt của đá. Quặng có cấu tạo đốm, dải...chúng đặc trưng cho kiểu nhiệt dịch lấp đầy.

Về thành phần khoáng vật quặng tương đối đơn giản (sphalerit - galenit - chalcopyrite - pyrite - 
tetraedrit - pyrotin). Đới quặng II có thành phần phức tạp hơn, chứng tỏ có sự bổ sung thành phần vật chất cho dung dịch quặng. Trong thành phần hoá học có thể thấy rõ lượng kẽm ở đới I lớn hơn chì còn ở đới II thì ngược lại. Khoáng vật spharlerit ở đới I có hiện tượng bị nén ép tạo vết rạn trong khi ở đới II không thấy hiện tượng đó, chứng tỏ sphalerit được hình thành sớm hơn. Từ những đặc điểm này cho thấy quặng chì - kẽm $\mathrm{Na}$ Sơn có nguồn gốc nhiệt dịch nhiệt độ trung bình - thấp, có cùng nguồn gốc dung dịch nhưng đã trải qua những giai đoạn lắng đọng khác nhau. Tùy thuộc vào giai đoạn xâm nhiễm của dung dịch mà ở mỗi nơi, mỗi lúc do điều kiện môi trường đã tạo thành tổ hợp quặng về định lượng có khác nhau. Ở giai đoạn đầu của quá trình vận hành, dung dịch nhiệt dịch tích tụ ở đới I, tại đây quá trình tích tụ kim loại mà khởi đầu là sắt và một lượng lớn kẽm, tiếp đó mới đến đồng và chì..., sau đó lại xảy ra một đợt xâm nhiễm mới của dung dịch nhiệt dịch đã được tăng cường về mặt thành phần, đồng thời chúng cũng hòa tan vật chất đá vây quanh làm giàu thêm thành phần dung dịch quặng và lại tiếp tục quá trình phân dị mới - quá trình tích tụ vật chất mới lại xảy ra, nhưng quá trình phân dị này xảy ra triệt để hơn và kết quả là thành phần quặng phức tạp hơn- đó chính là đa thành phần quặng ở đới II. Giai đọan đầu của sự phân dị tạo nên tổ hợp thành phần: sphalerit - galenit - pyrit...(đới quặng I). Giai đoạn sau tạo nên tổ hợp thành phần: galenit - sphalerit pyrit - chalcopyrit - tetraedrit ....argentit (đới quặng II). Sau khi giai đoạn tạo quặng nội sinh kết thúc, trong môi trường giàu ôxy hơn nữa thì quặng nội sinh bị biến đổi và các khoáng vật thứ sinh của $\mathrm{Pb}$, $\mathrm{Zn}, \mathrm{Cu}$ được hình thành: Serucit, smixonit, anglerit, bornit, covelin,...chúng tạo các viền bao quanh galenit, sphalerit, chalcopyrite...

Nghiên cứu đặc điểm phân bố quặng hoá khu $\mathrm{Na}$ Sơn cho thấy mức độ bóc mòn từ đới quặng I sang đới quặng II giảm dần, vì thế đới II còn có triển vọng quặng nằm ở dưới sâu.

Tiền đề tìm kiếm quặng chì - kẽm cho khu vực là các tập đá trầm tích lục nguyên - carbonat, các tập đá trầm tích lục nguyên - carbonat xen các lớp phun trào, các thể xâm nhập thuộc phức hệ granitoit á núi lửa Tòng Bá, các đới giao nhau của hệ thống đứt gãy $\mathrm{TB}$ - ĐN và á kinh tuyến, đặc biệt chú ý đến cấu trúc vòm của các lớp cận kề đứt gãy, các đới biến đổi nhiệt dịch,...
Hoạt động kiến tạo sau tạo quặng chắc chắn đã xảy ra mạnh mẽ, một mặt chúng kế thừa các đứt gãy liên quan tới tạo quặng và tạo nếp uốn, mặt khác chịu ảnh hưởng của đứt gãy phân đới cấu trúc (rìa đới). Như vậy những đứt gãy hướng Đông Bắc - Tây Nam ở khu vực nghiên cứu sẽ là những đứt gãy trượt gây dịch chuyển, do vậy cần phải chú ý tới sự có mặt của chúng trong tìm kiếm cũng như trong quá trình khai thác.

Cũng cần phải nói thêm rằng, đặc thù khoáng hoá $\mathrm{Pb}, \mathrm{Zn}$ và các sulfur khác của mỏ $\mathrm{Na}$ Sơn là vô cùng phức tạp và mang tính gián đoạn lớn theo cả chiều ngang lẫn chiều sâu, vì vậy trong quá trình khai thác cần kết hợp với nghiên cứu địa chất cấu trúc.

\section{$T \grave{I} I L I \hat{E} U D \tilde{A N}$}

[1] Trần Đình Bát và nnk, 1989: Báo cáo kết quả tìm kiếm đánh giá quặng chì - kẽm $\mathrm{Na}$ Sơn và tìm kiếm sơ bộ khu Tàng Khoảng - Tà Pan - Suối Thâu, Hà Tuyên. Lưu trữ Cục địa chất và khoáng sản Việt Nam, Hà Nội.

[2] Dovjkov A.E., 1965: Địa chất miền Bắc Việt Nam. Nxb KH và KT, Hà Nội.

[3] Vũ Xuân Độ, 1994: Khái quát về sinh khoáng Đông Bắc Bắc Bộ trong Phanerozoi. TC Địa chất, A 221, 24-34.

[4] Gospođinov G.R., Nguyễn Nghiêm Minh, Nguyễn Văn Hoc, 1987: Về các nguyên tố có ích đi kèm trong các thành hệ quặng chì - kẽm ở Việt Nam. TC Địa chất, A 180, 14-19.

[5] Ivanov V.V., 1966: Địa hoá của các nguyên tố phân tán $\mathrm{Ga}, \mathrm{Ge}, \mathrm{Cd}$, In và $\mathrm{Tl}$ trong các mỏ nhiệt dịch, Nxb. Nedra, Moskva, 389 tr, (tiếng Nga).

[6] Ivanov V.V., Iusko-Xakharova O.E, 1974. Mỏ các nguyên tố phân tán $\mathrm{Re}, \mathrm{Se}, \mathrm{Te}, \mathrm{Cd}, \mathrm{Ga}, \mathrm{Tl}$, In và Sc. Trong sách “Các mỏ quặng Liên Xô", tập 3, tr.453-465, Nxb Nedra, Moskva, (tg. Nga).

[7] Hoàng Minh và nnk, 1992: Báo cáo đặc điểm phân bố vàng bạc và các nguyên tố hiếm khác trong quặng chì - kẽm vùng Tùng Bá - Na Sơn, Hà Giang. Lưu trữ Cục địa chất và khoáng sản Việt Nam, Hà Nội.

[8] Nguyê̂n Văn Nhân và nnk, 1974: Đặc điểm quặng hóa một số mỏ chì - kẽm, antimoan vùng Đông Bắc Việt Nam. Lưu trữ TTTL Địa chất. Cục Địa chất và Khoáng sản Việt Nam, HN. 
[9] Nguyễn Văn Nhân, 1977: Đặc điểm quặng hoá chì - kẽm Đông Bắc Việt Nam. Lưu trữ Viện TTTL Địa chất, Hà Nội.

[10] Nguyễn Văn Nhân, 2000: Một số đặc điểm của sphalerit trong các mỏ và tụ khoáng chì - kẽm thuộc các kiểu khác nhau và ý nghĩa thực tiễn của chúng. Tc. Địa chất, loạt $\mathrm{A}$, số dành cho Khoa Địa chất, Trường ĐH KHTN - ĐHQG HN.

[11] Vương Mạnh Sơn và nnk, 2003: Báo cáo địa chât và khoáng sản nhóm tờ Phúc Hạ tỷ lệ 1:50000. Lưu trữ Cục địa chất và khoáng sản Việt Nam, Hà Nội.
[12] Đặng Trung Thuận, 1998: Địa hóa nguyên tố, Nxb. ĐHQG Hà Nội, 111 tr, Hà Nội.

[13] Trần Văn Trị, Nguyễn Đình Uy và nnk, 1976: Sơ đồ kiến tạo miền bắc Việt Nam tỉ lệ 1:1000.000, Tc ĐC, loạt A (123), tr. 1-22, Hà Nội.

[14] Trần Văn Trị (chủ biên) và nnk, 2009: Địa chất và Tài nguyên Việt Nam. Nxb Khoa học Tự nhiên và công nghệ.

[15] Mai Thế Truyền và nnk,1997: Báo cáo địa chất và khoáng sản nhóm tờ Bảo Lạc tỷ lệ 1:50000. Lưu trữ Cục địa chất và khoáng sản Việt Nam, Hà Nội.

\section{SUMMARY}

\section{New reseach results on distributiion and compositional characteristics of the $\mathrm{Na}$ Son lead-zinc ore}

Detailed studies in structural geology, ore body distribution and ore component characteristics of the $\mathrm{Na}$ Son mine indicated:

- The ore bodies in the first zone mainly composed of sphalerite, minority of galenite, chalcopyrite related to carbonate-volcanic terrigenous sediment interposed of alternative extrusion. The ore body characterized by bed, vein, lenticle fit within surrounding rocks. Ore bed characteristics of replaced hydrothermal structure. The ore body almost denuded as far as bottom.

- The ore bodies in the second zone formed by galenite, less of sphalerite, chalcopyrite and ternadite lied in the tectonic fracture zone. The ore body characterized by vein occurred along clastic breccia, rock partings of syenitoid. The ore belong to filled hydrothermal. The top of ore body just exposed and potential part lied in the deep.

The ore's major elements characterized by high concentration of $\mathrm{Zn}$ (62.24-66.01 wt.\%); $\mathrm{Pb}$ (86.76 wt.\%), equivalent to rich $\mathrm{Zn}-\mathrm{Pb}$ mine of the world.

The ores have high content of rare elements such as: $\mathrm{Cu}$ (1-3 wt.\%); $\mathrm{Ag}(10-123 \mathrm{ppm})$; Cd (66-1450ppm); In (0.731.5ppm); Mo (110-800 ppm), Sb (10.8-89.3 ppm, some time it reaches 323ppm); Bi (0.6-10.3 ppm),...

Specific ratios of $\mathrm{Zn} / \mathrm{Pb}$ in the ore in first zone: 0.25-31.14; in the second zone (0.067-0.92); $\mathrm{Zn} / \mathrm{Cd}$ in the ore in first zone: $381.82-700$; in the second zone (87.5-204.44) presented the ore in first zone denuded in the lower part, the ore in the second zone exposed in the higher part. 